\section{Plant and soil nematodes from Lokchao Yangoupokpi Wildlife Sanctuary, Manipur, India}

\author{
N. Mohilal ${ }^{1}$, M. Pramodini ${ }^{2} \&$ L. Bina ${ }^{2}$ \\ 1,2 Parasitology Laboratory, Life Sciences Department, Manipur \\ University, Canchipur, Manipur 795003, India \\ Email: ${ }^{1}$ mohilaln@yahoo.co.in
}

The Lokchao Yangoupokpi Wildlife Sanctuary, renowned for its rich biodiversity, is situated in Chandel District of Manipur $\left(94^{\circ} 13^{\prime} 5^{\prime \prime}-\right.$ $\left.94^{\circ} 23^{\prime} 51^{\prime \prime} \mathrm{E} \& 24^{\circ} 13^{\prime} 51^{\prime \prime}-24^{\circ} 26^{\prime} \mathrm{N}\right)$ covers an area of $184.80 \mathrm{~km}^{2}$. The eastern side of the Sanctuary borders with Myanmar.

There is little information available on invertebrate fauna of the sanctuary, particularly on nematodes. In the present study soil samples were collected from the sanctuary to investigate about what nematode species are associated with different plant hosts. Nematodes are round, microscopic, un-segmented, transparent, thread-like animals, found in almost every kind of environment. These nematodes may be plantparasitic, predaceous, or free-living feeding on bacteria and other detritus food. Each nematode trophic group plays a significant role in the energy cycle of the habitat.

Nematodes were extracted from soil by sieving and decantation methods using Baermann's funnels; fixed in warm $4 \%$ formalin-acetic acid (1:1) solution and mounted in anhydrous glycerin. The analysis yielded 18 species of plant-parasites, 12 of predatory and nine of free-living nematodes which belonged to 12 families under three orders (Table 1)

The present study shows rich nematode diversity in Lokchao Yangoupokpi Wildlife Sanctuary. Twenty-five genera of nematodes were encountered. Of these 12 genera consisting of 18 species belong to the phytonematode group, six genera consisting of nine species belong to the free-living group while seven genera consisting of 12 species belong to the predatory group. The parasitic nematodes encountered were ectoparasites. No significant external symptoms due to the parasitic nematodes could be found. More intensive survey in the deep interior areas of the sanctuary will yield more species of nematodes.

\section{References}

Altherr, E. (1953). Nematodes du sol du Jura vaudois et franca is 1. Bulletin. de la Société Vaudoise des Sciences Naturelles 65: 429-460

Date of publication 26 March 2009

ISSN 0974-7907 (online) | 0974-7893 (print)

Editor: Anwar L. Bilgrami

\section{Manuscript details:}

Ms \# 01537

Received 11 March 2006

Final revised received 25 October 2008

Finally accepted 05 November 2008

Citation: Mohilal, N., M. Pramodini \& L. Bina (2009). Plant and soil nematodes from Lokchao Yangoupokpi Wildlife Sanctuary, Manipur, India. Journal of Threatened Taxa 1(3): 188-189.

Copyright: (c) N. Mohilal, M. Pramodini \& L. Bina 2009. Creative Commons Attribution 3.0 Unported License. JoTT allows unrestricted use of this article in any medium for non-profit purposes, reproduction and distribution by providing adequate credit to the authors and the source of publication.

\section{OPEN AGGESS | FREE DOWNLOAD}

Andrassy, I. (1958). Yber das system der Mononchiden (Mononchidae Chitwood, 1937: Nematoda). Annales Historico-Naturales Musei Nationalis Hungarici 50: 151-171.

Andrassy, I. (1959). Taxonomische ubersicht der Dorylaimen (Nematoda). I. Acta Zoologica Academiae Scientiarum Hungaricae 5: 191-240.

Andrassy, I. (1982). The Genera and species of the family Tylenchidae Orley, 1880 (Nematoda). The genus Coslenchus Siddiqi, 1978. Acta Zoologica Academiae Scientiarum Hungaricae. 28:198-232

Andrassy, I. (1993). A taxonomic survey of the family Anatonchidae (Nematoda) Opuscula Zoologica Budapestinensis 25:11-35.

Bajaj, H.K. \& D.S. Bhatti (1978). Two new species of Basiria Siddiqi, 1959 (Tylenchida) from Haryana, India. Indian Journal of Nematology 8: 95-101.

Cobb, N.A. (1893). Nematodes mostly Australian and Fijian. Macleay Memorial Volume; Linnean Society of New South Wales 252-308.

Cobb, N.A. (1893). Nematodes worms found attacking sugarcane(In plant diseases and their remedies) Agricultural Gazette of New South Wales 4: 808833.

Cobb, N.A. (1906). Fungus maladies of the sugarcane. IX. Free-living nematodes inhabiting the soil about the roots of cane, and their relation to root diseases. Hawaiian sugar planters Assoc. Bulletin of Experimental Station Division Pathology and Physiology 5: 163-195.

Cobb, N.A. (1917). The Mononch (Mononchus Bastain, 1965). A genus of free living predatory nematodes. Soil Sciences 3: 431-486.

Cobb, N.A. (1920). One hundred new nemas (Type species of 100 new genera) Coutribution to Science of Nematology (Cobb) 32: 217-343.

Cobb, N.A. (1913). New nematode genera found inhabiting freshwater and nonbrackish soils. Journal of the Washington Academy of Sciences 3: 437-444. pp1.

De Grisse, A. \& P.A.A. Loof (1965). Revision of the genus Criconemoides (Nematoda). Meded. Land Hooqesch Opzock-stus. Gent. 30: 577-603.

De Man, J.C. (1921). Nouvelles recherches sur less nematodes libres terricoles de la Hollanda. Capita Zoologica 1: 3-62.

Dhanachand, Ch., K. Renubala \& N. Mohilal (1991). Two new species of Dorylaimida from Manipur, India. Uttar Pradesh Journal of Zoology 11(2): 8186.

Dhanachand, Ch. K. Renubala \& N. Mohilal (1991). The new genus Morenchus denticulus n.gen.,n.sp. and a new species of Parahadronchus from Moreh, Manipur, India. Current Nematology 2(2): 135-138

Gambhir, R.K. \& Ch. Dhanachand (1990). Nematodes of fruit plants in ManipurI: Three known and one new species of Thornenema Andrassy,1959 (Thornematidae: Dorylaimida) from Manipur, India. Indian Journal of Hill Farming 3(2): 33-37.

Gambhir, R.K. \& Ch. Dhanachand (1990). Nematodes of fruit plants in Manipur VIII: one new and three known species of Axonchium (Dorylaimida: Belondiridae). Current Nematology 1(2): 163-166.

Jairajpuri, M,S, and Khan, W.V. (1982). Predatory Nematodes (Mononchida) with Special Reference to India. Associated Publishing Company, New Delhi, 131pp.

Jairajpuri, M.S. (1963). On the status of the subfamilies Rotylenchoidinae Whitehead, 1958 \& Telotylenchinae Siddiqi, 1960. Zeitschrift fiur Parasitenkunde 23: 320-323.

Jairajpuri, M.S. (1964). Studies on Nygellidae n.fam.and Belondiridae Thorne, 1936 (Nematoda: Dorylaimoidea) with description of ten new species from India. Proceedings of Helminthological Society Washington 31: 173-187.

Jairajpuri, M.S. (1964). Stuidies on Campydorinae and Leptonchidae (Nematoda: Dorylaimoidea) with description of Basirotyleptus basiri n. gen. n. sp. from India. Proceedings of Helminthological Society of Washington 31: 59-64.

Jairajpuri, M.S. (1969). Studies on Mononchida of India. The genera Hadronchus, Iotonchus and Miconchus and a revised classification of Mononchida new order Nematologica 16: 213-221.

Javed, R. (1982). Neobasiria citrigen.n., sp.n. in the subfamily Basirinae (Tylenchida: Psilenchidae) from Ramtake, Maharastra, India. Indian Journal of Nematology 12(1): 107-110

Lordello, L.G.E. (1955). On the morphology of Proleptonchus aestivus n.gen., $\mathrm{n}$. sp. and Dorylaimus lourdesae n.sp., two new soil nematodes from Brazil Proceedings of Helminthological Society of Washington 22: 72-75.

Luc, M. \& D.J. Raski (1981). Status of the genera Macroposthonia, Criconemoides, Criconemella and Xenocriconemella (Criconematidae: Nematoda). Revue de Nematology 4(1): 3-21.

Luc, M. (1959). Nouveaux criconematidae de la zone entertropicale (Nematoda: Tylenchida). Nematologica 4: 6-22.

Mohilal, N., Y. Anandi \& Ch. Dhanachand (1996). Three known species of 
Table 1. List of plant and soil nematode species recorded from Lokchao Yangoupokpi Wildlife Sanctuary

\begin{tabular}{|c|c|c|}
\hline Namatodes & Host & Authors \\
\hline $\begin{array}{l}\text { Plant-parasitic } \\
\text { Aglenchus muktii } \\
\text { Coslenchus assamensis } \\
\text { Coslenchus costatus } \\
\text { Boleodorus citri } \\
\text { Boleodorus bambosus } \\
\text { Basiria hissariensis } \\
\text { Helicotylenchus dihystera } \\
\text { Ogma ornama } \\
\text { Criconemella furniae } \\
\text { Criconemella onoensis } \\
\text { Criconemella sphaerocephala } \\
\text { Criconemella ornata } \\
\text { Discocriconemella limitanea } \\
\text { Hemicriconemoides dipterocarpus } \\
\text { Hemicriconemoides mangiferae } \\
\text { Hemicycliophora typica } \\
\text { Xiphinema americanum } \\
\text { Xiphinemella moreatum }\end{array}$ & $\begin{array}{l}\text { Unidentified grasses } \\
\text { Cynodon dactylon Pers } \\
\text { Cynodon dactylon Pers } \\
\text { Plantago erosa } \\
\text { Bambusa tulda } \\
\text { Unidentified grasses } \\
\text { Cynodon dactylon Pers. } \\
\text { Asplenium delitescens } \\
\text { Grass } \\
\text { Bambusa griffithiana } \\
\text { Ficus glomerata Roxb. } \\
\text { Cynodon dactylon Pers } \\
\text { Asplenium delitescens } \\
\text { Dipterocarpus tuberculatus Roxb. } \\
\text { Bambusa balcooa Roxb. } \\
\text { Ficus glomerata Roxb. } \\
\text { Mangifera indica Linn } \\
\text { Dipterocarpus tuberculatus Roxb }\end{array}$ & $\begin{array}{l}\text { Phukan \& Sanwal } 1980 \\
\text { (Phukan \& Sanwal 1980); Andrassy } 1982 \\
\text { (De Man, 1921); Siddiqi } 1978 \\
\text { (Javed 1982); Siddiqi } 1986 \\
\text { Mohilal et al. } 1999 \\
\text { Bajaj \& Bhatti } 1978 \\
\text { (Cobb, 1893); Sher 1961 } \\
\text { Mohilal \& Dhanachand 1998 } \\
\text { (Luc 1959); Luc \& Raski } 1981 \\
\text { (Luc 1959); Luc \& Raski } 1981 \\
\text { (Taylor 1936); Luc \& Raski } 1981 \\
\text { (Raski 1958); Luc \& Raski } 1981 \\
\text { (Luc 1959); De Grisse \& Loof } 1965 \\
\text { Mohilal et al. 2004 } \\
\text { Siddiqi 1961 } \\
\text { de Man 1921 } \\
\text { Cobb 1913 } \\
\text { Dhanachand et al. } 1991\end{array}$ \\
\hline $\begin{array}{l}\text { Non-parasitic } \\
\text { Belondira clava } \\
\text { Axonchium saccatum } \\
\text { Axonchium amplicolle } \\
\text { Axonchium asacculum } \\
\text { Thornenema cavalcantii } \\
\text { Lagenonema clavicaudatum } \\
\text { Tylencholaimus lokus } \\
\text { Tylencholaimus minutus } \\
\text { Proleptonchus amphidius }\end{array}$ & $\begin{array}{l}\text { Vanguirea spinosa Hooke } \\
\text { Spondias pinnata (Linn.f.) Kurz. } \\
\text { Dipterocarpus turbinatus } \\
\text { Quercus serrata } \\
\text { Tamarindus indica Linn } \\
\text { Punica granatum } \\
\text { Dipterocarpus tuberculatus Roxb. } \\
\text { Quercus dealbata } \\
\text { Cynodon dactylon Pers. }\end{array}$ & $\begin{array}{l}\text { Thorne } 1939 \\
\text { Jairajpuri } 1964 \\
\text { Cobb } 1920 \\
\text { Siddiqi } 1968 \\
\text { (Lordello 1955); Andrassy 1959 } \\
\text { (Gambhir \& Dhanachand 1990); Mohilal et al. } 1996 \\
\text { Mohilal \& Dhanachand } 2003 \\
\text { Vinciguerra } 1986 \\
\text { Jairajpuri } 1964\end{array}$ \\
\hline $\begin{array}{l}\text { Predatory } \\
\text { Aquatides aquaticus } \\
\text { Coomansus icarus } \\
\text { Coomansus conoidus } \\
\text { Cobbonchus impositus } \\
\text { lotonchus indicus } \\
\text { lotonchus terminus } \\
\text { Hadronchus denticulus } \\
\text { Parahadronchus subhonicus } \\
\text { Parahadronchus andamanicus } \\
\text { Mylonchulus index } \\
\text { Mylonchulus minor } \\
\text { Mylonchulus sigmaturus }\end{array}$ & $\begin{array}{l}\text { Psidium guajava L. } \\
\text { Vanguirea spinosa Hooke } \\
\text { Wild grass } \\
\text { Grass } \\
\text { Dipterocarpus tuberculatus Roxb. } \\
\text { Imperata cylindrica Beauv. } \\
\text { Imperata cylindrica Beauv. } \\
\text { Dipterocarpus tuberculatus Roxb. } \\
\text { Psidium guajava Linn } \\
\text { Musa paradisiaca L. } \\
\text { Unidentified grass } \\
\text { Unidentified grass }\end{array}$ & $\begin{array}{l}\text { (Thorne 1930); Thorne } 1974 \\
\text { Jairajpuri \& Khan } 1982 \\
\text { Mohilal \& Dhanachand } 1998 \\
\text { Mohilal \& Dhanachand } 1998 \\
\text { Jairajpuri } 1969 \\
\text { Mohilal et al. } 2000 \\
\text { (Dhanachand et al. 1991); Andrassy, } 1993 \\
\text { Dhanachand et al. } 1991 \\
\text { (Jairajpuri 1963); Mulvey } 1978 \\
\text { (Cobb 1906); Cobb } 1917 \\
\text { (Cobb 1893); Andrassy } 1958 \\
\text { (Cobb 1917); Altherr } 1953\end{array}$ \\
\hline
\end{tabular}

Lagenomema Andrassy, 1987 from Manipur. Uttar Pradesh Journal of Zoology 16: 36-38.

Mohilal, N., Y. Anandi \& Ch. Dhanachand (1999). Two new species of Boleodorus Thorne, 1941 and male report of Neopsilenchus affinis. Current Nematology $8(1 \& 2): 17-22$.

Mohilal, N., Y. Anandi \& Ch. Dhanachand (2004). Two known and one new species of Nemata from Manipur. Uttar Pradesh Journal of Zoology 24(1): 7378.

Mohilal, N., Y. Anandi \& Ch. Dhanachand (2000). Studies on soil nematodes of Manipur-IX: Two new species and a male record of Iotonchinae. Uttar Pradesh Journal of Zoology 20(2): 175-181.

Mohilal, N. \& Ch. Dhanachand (1998). Three new species of Mononchs (Nematoda: Mononchida). Indian Journal of Nematology 27(2): 179-186.

Mohilal, N. \& Ch. Dhanachand (2003). Studies on soil nematodes of ManipurXI: Two new and one known of Tylencholaimus. Uttar Pradesh Journal of Zoology 23(1): 87-92.

Mulvey, R.H. (1978). Predaceous nematodes of the family Mononchidae from the Mackenzei and porcupine river system \& Somerset Island. N.W.T., Canada. Canadian Journal of Zoology 56: 1847-1868.

Phukan, P.N. \& K.C. Sanwal (1980). Two new species of Aglenchus and record of Cephalenchus leptus (Tylenchidae: Nematoda) from Assam. Indian Journal Nematology 10: 28-34.

Raski, D.J. (1958). Nomenclatorial notes on the genus Criconemoides (Nematoda: Criconematidae) with a key to the species. Proceedings of Helminthological Society of Washington 25:139-142.

Sher, S.A. (1961). Revision of the Hoplolaiminae (Nematoda) 1. classification of nomimal genera and nominal species. Nematologica 6(2): 155-159.

Siddiqi, M.R. (1968). Crateronema n.gen. (Crateronematinae. N.fan.), Poranemella n.gen. (Lordellonematinae n. subfamily) \& Chrysonemoides n.gen.
(Chrysonematidae fam.) with a revised classification of Dorylaimoidea (Nematoda). Nematologica 15: 61-100.

Siddiqi, M.R. (1978). The unusual position of the phasmids in Coslenchus costatus (De Man, 1912) gen.n.comb.n. and other Tylenchidae (Nematoda: Tylenchida). Nematologica. 24: 449-455.

Siddiqi, M.R. (1961). Studies on species of Criconematidae (Nematoda: Tylenchida) from India. Proceedings of Helminthological Society of Washington 28: $19-34$.

Siddiqi, M.R. (1986). Tylenchida Parasites of Plant and Insects. Commonwealth Agri. Bureaux., Commonwealth Institute of Parasitology, St. Albans, U.K. $\mathrm{X}+645 \mathrm{pp}$.

Taylor, A.L. (1936). The genera and species of the Criconematinae, a subfamily of the Anguillulinidae (Nematoda). Transaction of American Microbiological Society 55: 391-421.

Thorne, G. (1930). PREDACEOS nemas of the genus Nygolaimus and a new genus Sectonema. Journal of the Agricultural Research 41: 445-466.

Thorne, G. (1939). A monograph of the nematodes of the super family Dorylaimoides. Capita Zoologica 8:1-261.

Thorne, G. (1974). Nematodes of the Northern Great Plains. Part II. Dorylaimoides in part (Nematoda: Adenophorea). Technical Bulletin of Agricultural Experiment Station, South Dakota State University, Brooking. 41: 120 pp.

Vinciguerra, M.T. (1986). New and known species of Tylencholaimus De Man, 1876 (Dorylaimida: Nematoda) from Italian beech forest with a key to the species. Nematologia Mediterranea 14: 107-116.

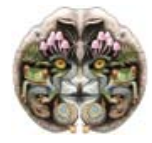

